\title{
PENDUGAAN POPULASI PESUT (Orcaella brevirostris) PADA BULAN FEBRUARI DI RESORT SUNGAI PERLU TAMAN NASIONAL TANJUNG PUTING KALIMANTAN TENGAH
}

\section{(Population Estimation of Irrawaddy Dolphin (Orcaella brevirostris) at Sungai Perlu Resort on February in Tanjung Puting National Park, Central Kalimantan)}

\author{
FAJAR RAHAYU $^{(*)}$, MUFLIHATI $^{1)}$, SOFWAN ANWARI ${ }^{1)}$ DAN BUDI SURIANSYAH ${ }^{2)}$ \\ 1) Fakultas Kehutanan Universitas Tanjungpura, Jalan Imam Bonjol, Pontianak, Indonesia 78124 \\ 2) Taman Nasional Tanjung Puting, Jl. HM. Rafi'i Km. 2, Pangkalan Bun, Kotawaringin Barat, Indonesia 74112
}

*Email: fajarahayu28@gmail.com

Diterima 05 Oktober 2019 / Disetujui 19 Maret 2020

\begin{abstract}
Irrawaddy dolphin is one of dolphin species without snout that lives in fresh, brackish and salty water belong to the group of large marine mammals. Irrawaddy dolphin is determined as a conservation focus and priority of species in Indonesia and also included to the endangered species (IUCN Red list 2017). The decreasing number of individuals and increasing threats make this species increasingly threatened.. This study aims to estimate the population of Irrawaddy dolphin in the Sungai Perlu Resort SPTN Wilayah II Tanjung Puting national park in February which according to local fishermen is the most appropriate time to observe dolphins due to the sea wave conditions. The method used in this study is Capture-Mark-Recapture using a photo of the dorsal fin as the individual identity of each Irrawaddy dolphin. Estimation of the population using Chapman equation analysis. The results of the study captured total population of 55 individuals. The dorsal fin characteristics that dominate are ovoid, triangular, branched, and flat.
\end{abstract}

Keywords: Dorsal Fin, Irrawaddy Dolphin, Population, Tanjung Puting National Park

\section{ABSTRAK}

Pesut adalah jenis lumba-lumba tanpa moncong yang hidup pada air tawar, payau dan asin termasuk kedalam golongan mamalia laut besar. Pesut ditetapkan sebagai spesies yang menjadi fokus dan prioritas upaya konservasi jenis di Indonesia karena termasuk kedalam spesies endangered. Jumlah individu yang terus berkurang dan meningkatnya ancaman membuat spesies ini semakin terancam jumlahnya. Penelitian bertujuan untuk menduga populasi pesut yang berada di Resort Sungai Perlu SPTN Wilayah II Taman Nasional Tanjung Puting yang dilakukan pada bulan februari yang mana menurut nelayan lokal adalah waktu yang paling tepat untuk melakukan pengamatan pesut karena kondisi gelombang laut yang sedang tenang. Metode yang digunakan dalam penelitian ini adalah Capture-Mark-Recapture dengan menggunakan foto sirip punggung sebagai identitas individu setiap pesut. Pendugaan jumlah populasi menggunakan analisis persamaan Chapman. Hasil penelitian mendapatkan jumlah populasi pesut sebesar 55 individu. Karakteristik sirip punggung yang mendominasi adalah bulat telur, segitiga, bercabang, dan datar.

Kata kunci: pesut, populasi, sirip punggung, Taman Nasional Tanjung Puting

\section{PENDAHULUAN}

Taman Nasional Tanjung Puting (TNTP) terletak di ujung pesisir Propinsi Kalimantan Tengah, yaitu di Kabupaten Kotawaringin Barat dan Kabupaten Seruyan. TNTP dibagi menjadi tiga wilayah kerja, salah satunya adalah Seksi Pengelolaan Taman Nasional (SPTN) Wilayah II Kuala Pembuang. Menurut pembagian zonasi, TNTP membagi wilayah menjadi sembilan zona di antaranya adalah zona perlindungan bahari. Resort Sungai Perlu merupakan salah satu zona perlindungan bahari yang terletak di SPTN Wilayah II (Balai Taman Nasional Tanjung Puting 2017). Resort Sungai Perlu memiliki keanekaragaman hayati berupa flora dan fauna. Hasil pendataan di Resort Sungai Perlu secara periodik selama lebih kurang 3 tahun tercatat 73 jenis mamalia termasuk di antaranya mamalia laut. Mamalia laut di kawasan Resort Sungai Perlu tercatat tiga jenis yaitu lumba-lumba punggung bungkuk (Sousa chinensis) lumba-lumba tanpa sirip punggung (Neophocaena phocaenoides), dan pesut (Orcaella brevirostris), ketiganya mengalami penurunan jumlah individu terutama individu dewasa (IUCN Red-list 2017). Spesies tersebut sering terlihat muncul dan bermain di laut Sungai Perlu (Balai Taman Nasional Tanjung Puting 2017).

Pesut (O. brevirostris) atau disebut juga Irrawaddy dolphin adalah jenis lumba-lumba tanpa moncong yang termasuk ke dalam famili Delphinidae, merupakan mamalia laut besar yang hidup pada air tawar, payau dan asin. Pesut di Kalimantan diketahui berada di Kalimantan Timur (Noor 2016), Kalimantan Barat (Purnomo et al. 2017) dan Kalimantan Tengah (Balai Taman Nasional Tanjung Puting 2017). Pesut telah ditetapkan sebagai cetacea sungai 'fakultatif' mempertimbangkan 
kemampuan beradaptasi mereka di laut dan air tawar (Leatherwood dan Reeves 1994)

Populasi pesut berdasarkan IUCN (2017) telah diberi status terancam atau endangered. Keberadaan pesut yang ada di Sungai Mahakam Kalimantan Timur terancam punah karena populasinya menurun dari 300 individu menjadi 92 individu (Noor et al. 2013). Keberadaan pesut di Kamboja (WWF Kamboja 2017), Sungai Mekong, Vietnam (WWF 2019) mengalami kenaikan dari 78 ke 92 individu.

Indonesia menetapkan pesut sebagai satwa yang dilindungi berdasarkan Peraturan Menteri Lingkungan Hidup dan Kehutanan Nomor P.106 Tahun 2018 tentang Jenis Tumbuhan dan Satwa Dilindungi. Berdasarkan Arahan Strategis Konservasi Spesies Nasional dalam Peraturan Menteri Kehutanan No. 57 Tahun 2008 menyatakan bahwa pesut ditetapkan sebagai spesies yang menjadi fokus prioritas upaya konservasi jenis di Indonesia dengan tingkat prioritas sangat tinggi. Sebagai salah satu wilayah konservasi di Indonesia, keberadaan pesut di TNTP menjadi satwa kunci (key features) dan spesies prioritas yang perlu diperhatikan kelestariannya. Informasi tentang jumlah populasi merupakan salah satu hal penting dalam melestarikan dan menentukan status kelangkaan spesies satwa yang terancam punah, dalam konteks pengelolaan yang intensif, dinamika populasi menjadi sangat penting untuk dipahami (Beasley 2007). Sejak 1970, foto identifikasi merupakan alat yang berharga untuk menentukan dinamika populasi, sosial organisasi, distribusi dan pola pergerakan bagi banyak spesies cetacea (Kreb 2004). Informasi mengenai populasi pesut yang ada di TNTP belum tersedia, hal tersebut menyebabkan tindakan konservasi terhadap pesut sulit dilakukan. Sehingga untuk mendukung rencana strategi konservasi, maka pendugaan jumlah populasi pesut di TNTP perlu dilakukan.

\section{METODE PENELITIAN}

Penelitian dilaksanakan di Resort Sungai Perlu TNTP dengan panjang jalur $30 \mathrm{~km}$ di sepanjang garis pantai Sungai Perlu yaitu pada sembilan titik pengamatan di antaranya Sungai Ranggau, Sungai Leger, Sungai Batang Bahalang Kecil, Sungai Paku, Sungai Batang Bahalang Besar, Sungai Tulis, Sungai Gantingan dan Sungai Perlu yang seluruhnya berada di Resort Sungai Perlu. Starting point dimulai dari batas Kawasan yaitu di Sungai Ranggau.

Penelitian dilakukan pada bulan februari 2019 yang berlangsung selama 14 hari yaitu pada 7 hari pertama, dan diulang pada dua minggu berikutnya. Pengamatan pada bulan februari dilakukan karena menurut nelayan lokal pada bulan tersebut kondisi gelombang laut tenang sehingga akan mengoptimalkan pengamatan pesut. Pengamatan dilakukan setiap hari mulai pukul $05.00-$ 18.00 WIB. Alat yang digunakan adalah kamera digital dengan lensa $300 \mathrm{~mm} / \mathrm{f}$. 5.6, binocular, monocular, counter dan range finder. Pengamatan dilakukan dengan menggunakan metode Capture-mark-recapture secara perpendicular yaitu penangkapan objek secara visual dengan posisi pengamat tegak lurus objek penelitian (Noor 2013). Pengamatan dilakukan di sepanjang garis pantai Sungai Perlu yang meliputi keseluruhan wilayah perlindungan bahari laut Resort Sungai Perlu dengan menggunakan kendaraan bermotor mengikuti pergerakan pesut. Pesut yang tertangkap kamera kemudian dimasukkan kedalam katalog sirip punggung dan diidentifikasi. Perkiraan jumlah populasi menggunakan metode perhitungan langsung yaitu jumlah individu yang teridentifikasi berdasarkan karakteristik sirip punggung.

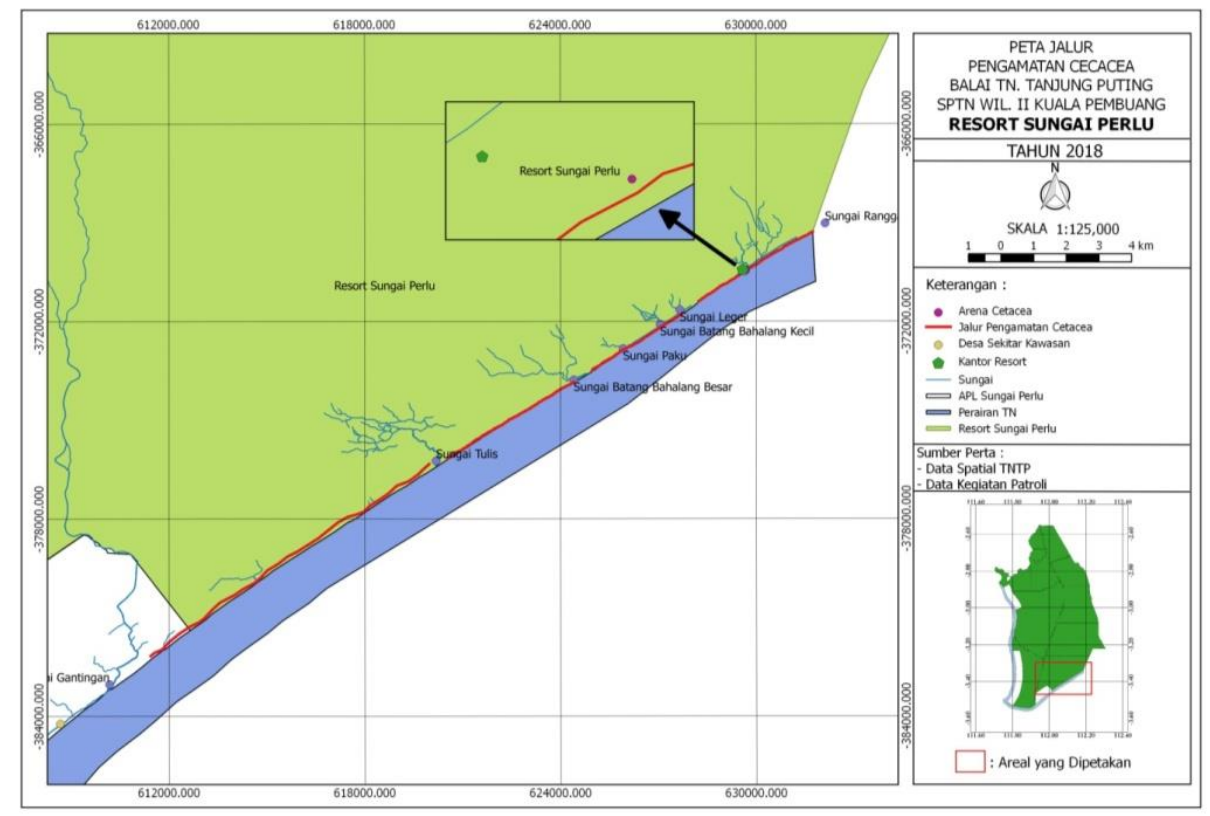

Gambar 1 Peta jalur pengamatan pesut 
Identifikasi foto digunakan sebagai alat yang sangat diperlukan dalam evaluasi ukuran populasi, kejadian, interaksi sosial, distribusi dan pola migrasi banyak spesies cetacea sejak tahun 1970 (Hammond et al. 1990) yang kemudian dimasukkan dalam persamaan Chapman (Sutherland 1996 dalam Noor 2013) :

$$
N=\frac{(\mathrm{n} 1+1)(\mathrm{n} 2+1) \ldots+\mathrm{n}}{(\mathrm{m}+1)}-1
$$

Keternagan:

$\mathrm{N}=$ Jumlah seluruh populasi

$\mathrm{n}_{1}=$ Jumlah individu yang teridentifikasi pada survei pertama

$\mathrm{n}_{2}=$ Jumlah individu yang teridentifikasi pada survei kedua

$\mathrm{m}=$ Jumlah individu yang telah diidentifikasi pada survei pertama dan kembali ditemukan pada survei kedua.

$$
\begin{gathered}
\mathrm{CL} 1,2=\frac{\mathrm{n} 1}{\mathrm{~W} 1,2} \\
\mathrm{CV}(\mathrm{N})=\mathrm{N}^{-1} \sqrt{\frac{\mathrm{n} 1^{2(\mathrm{n} 2+1)(\mathrm{n} 2-\mathrm{m})}}{(\mathrm{m}+1)^{2}(\mathrm{~m}+2)}}
\end{gathered}
$$

Dimana

dan

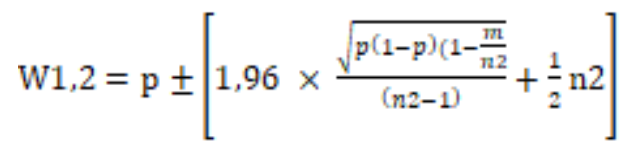

$$
\mathrm{p}=\frac{m}{n 2}
$$

Keterangan:

$\mathrm{CL}$ = Selang Kepercayaan

$\mathrm{CV}=$ Koefisien variabel

W 1,2 = Selang kepercayaan tertinggi dan terendah.

\section{HASIL DAN PEMBAHASAN}

\section{Kondisi dan Waktu Perjumpaan Pesut}

Pesut teramati kamera di dua tempat yaitu Sungai Perlu dan Sungai Gantingan, hal ini karena pada lokasi tersebut waktu pengamatan bertepatan dengan kemunculan pesut, sedangkan pada lima tempat lainnya kemunculan pesut tidak bersamaan dengan waktu pengamatan. Perjumpaan pesut juga dipengaruhi oleh keberadaan pesut yang sedang mencari makan dan bermain. Sungai Perlu dan Sungai Gantingan merupakan tempat bertemunya arus sungai dan laut, dimana di tempat tersebut banyak dijumpai ikan-ikan kecil yang bermunculan ke permukaan air. Menurut Noor (2016) karakteristik bio-fisik yang disukai pesut di antaranya adalah ketersediaan makanan yang melimpah, keberadaan muara anak sungai dan perairan yang dalam. Pertemuan arus anak-anak sungai dengan induknya, menciptakan pusaran air yang kuat yang dapat memerangkap ikan yang menjadi mangsa pesut.

Perjumpaan pesut sering terjadi pada pagi hari yaitu pukul 05.00 WIB - 10.00 WIB saat kondisi air laut sedang pasang dengan rentang waktu perjumpaan masing masing berkisar antara 2 menit - 15 menit. Perjumpaan dengan kelompok pesut terkadang juga disusul dengan kelompok pesut lainnya pada waktu yang hampir bersamaan. Pada kondisi ini pesut bergerak untuk mencari makan dan bermain di sekitar pantai. Kenaikan air laut memberikan pengaruh terhadap gerak renang pesut. Irvine dan Wells (1972); Harzen (1998) dalam Wahyudi (2010) menyatakan bahwa lumba lumba (Cetaceae) di Saratosa, Florida memanfaatkan arus air pasang menuju perairan dangkal dekat dengan lamun untuk mencari makan terutama memangsa ikan. Fluktuasi suhu dan salinitas dari badan air yang berbeda memiliki dampak yang sangat besar pada distribusi cetacea (Baumgartner dan Mate 2005). Selain itu, pola distribusi cetacean dipengaruhi oleh musim dan waktu

\begin{tabular}{|c|c|c|c|c|c|c|}
\hline No. & Minggu ke - & Tanggal & Waktu & Rentang waktu & Jumlah & Cuaca \\
\hline 1 & & $04 / 02 / 2019$ & 06.05 & 5 menit & 5 & Berawan \\
\hline 2 & & $05 / 02 / 2019$ & 06.23 & 3 menit & 5 & Berawan \\
\hline 3 & Minggu I & $09 / 02 / 2019$ & 05.29 & 7 menit & 2 & Berawan \\
\hline 4 & & 09/02/2019 & 05.40 & 5 menit & 5 & Berawan \\
\hline \multirow[t]{2}{*}{5} & & $09 / 02 / 2019$ & 06.03 & 15 menit & 3 & Berawan \\
\hline & & \multicolumn{2}{|c|}{ Total } & & 20 & \\
\hline 1 & & $16 / 02 / 2019$ & 09.37 & 8 menit & 3 & Berawan \\
\hline 2 & & $17 / 02 / 2019$ & 14.35 & 5 menit & 3 & Berawan \\
\hline 3 & Minggu II & $17 / 02 / 2019$ & 14.37 & 10 menit & 2 & Berawan \\
\hline 4 & & $18 / 02 / 2019$ & 07.25 & 4 menit & 2 & Berawan \\
\hline \multirow[t]{2}{*}{5} & & $19 / 02 / 2019$ & 06.49 & 12 menit & 5 & Cerah \\
\hline & & \multicolumn{2}{|c|}{ Total } & & 15 & \\
\hline
\end{tabular}
dalam sehari karena banyaknya sumber daya musiman, keberadaan spesies lain dan struktur habitat (Daura-Jorge et al. 2005).

Tabel 1. Hasil Pengamatan Pesut 
Karakteristik sirip punggung pesut secara garis besar ada empat bentuk, yaitu bulat telur, segi tiga, bercabang, dan datar, yang didominasi oleh bentuk segitiga dengan ujung bundar. Bentuk sirip punggung tersebut tidak ada yang sama dan menunjukkan perbedaan yang signifikan pada setiap individu. Noor (2016) menyebutkan bahwa sirip punggung pesut menjadi pembeda pada setiap individu dan berfungsi sebagai sidik jari sehingga karakteristik sirip punggung dapat digunakan untuk mengidentifikasi dan menghitung jumlah populasi. Tidak ada standar khusus dalam mengidentifikasi pesut, selama sirip punggung dari ujung hingga bagian bawahnya dapat terlihat dengan jelas maka foto tersebut dapat digunakan untuk identifikasi (Parra dan Corkeron 2001).

Setiap bentuk sirip punggung pesut menandakan identitas dan ciri khusus individu, bentuk dan ciri khusus ini dapat digunakan untuk menghitung jumlah populasi pesut sehingga dapat diperkirakan jumlah individu dari sirip punggung yang tertangkap kamera.

\section{Pendugaan Populasi Pesut (Orcaella brevirostris)}

Hasil analisis foto sirip punggung pesut yang berada di Resort Sungai Perlu pada pengamatan pertama teridentifikasi 20 individu (variabel $\mathrm{n} 1$ ) dan pengamatan kedua diidentifikasi 15 individu berbeda (variabel n2). Hasil analisis dari kedua pengamatan tersebut, didapatkan lima individu yang ditemukan pada pengamatan pertama dan ditemukan kembali pada pengamatan kedua (variabel $\mathrm{m} 2$ ). Pendugaan populasi berdasarkan variabel $\mathrm{n} 1$, $\mathrm{n} 2$ dan $\mathrm{m} 2$ menggunakan persamaan Chapman adalah sebanyak 55 individu $(\mathrm{CV}=$ $30 \%$; selang kepercayaan $95 \%=76,2-79,6)$. Jumlah populasi ini lebih sedikit dibandingkan dengan yang ada di Sungai Mahakam Kalimantan Timur dengan jumlah populasi 92 individu (Noor 2013), di Sungai Mekong (Vietnam) 78-91 individu dan di Kamboja sebanyak 92 individu (WWF Kamboja 2017).

Jumlah individu adalah informasi penting untuk menentukan status kelangkaan dan merupakan langkah awal untuk melakukan pelestarian suatu populasi spesies satwa liar yang terancam punah. Jumlah individu suatu populasi juga dapat memberikan gambaran tentang kondisi habitat dan perkembangan suatu populasi yang berguna untuk merancang strategi pengelolaan (Noor 2016).

\section{Faktor yang Mempengaruhi Kemunculan Pesut Mahakam}

\section{a. Pasang surut air laut}

Menurut pengamatan pesut yang terdapat di Resort Sungai Perlu sering dijumpai pada saat air laut akan pasang. Pesut akan jarang ditemui saat kondisi air surut karena kedalaman air di daerah pantai rendah sehingga menyulitkan pesut untuk berenang. Menurut Kreb dan Budiono dalam Noor (2016) faktor yang menyebabkan suatu tempat disukai oleh pesut mahakam adalah perairan yang dalam. Saat kondisi air tinggi/banjir, pesut mahakam bisa menjelajah jauh dari habitat intinya ke hampir seluruh wilayah yang dikenal sebagai daerah sebarannya, termasuk danau-danau dan anak sungai (Noor 2016).

Tinggi pasang air ketika perjumpaan dengan pesut mahakam di Resort Sungai Perlu berkisar antara 1,0 m sampai $1,5 \mathrm{~m}$. Berdasarkan data pasang surut air laut Resort Sungai Perlu, perjumpaan dengan pesut mahakam sering terjadi pada pagi hari yaitu pukul 05.00 WIB10.00 WIB yaitu saat kondisi air laut sedang pasang dan satu kali ditemukan pada siang hari yaitu pukul 14.35 WIB. Hal ini diduga karena pada waktu pagi hari saat air laut sedang pasang, pesut mahakam bergerak untuk mencari makan. Air pasang memberikan pengaruh terhadap gerak renang mamalia air (lumba-lumba). Irvine dan Wells (1972); Harzen (1998) dalam Wahyudi (2010) meneliti tentang lumba lumba dengan famili Cetaceae mengatakan bahwa dekat Sarasota, Florida, lumba-lumba memanfaatkan arus air pasang menuju perairan dangkal dekat dengan lamun untuk mencari makan terutama memangsa ikan.

\section{b. Cuaca}

Kecamatan Seruyan Hilir terletak di Kabupaten Seruyan bagian selatan yang mana musim hujan masuk mulai dari Bulan Oktober minggu kedua hingga November minggu pertama 2018 dengan perbandingan Terhadap rata-rata (dasarian) +3 yang artinya awal musim hujan mundur 3 dasarian dari rata-ratanya (1 dasarian sama dengan 10 hari) sedangkan pada tahun 2019 diperkirakan musim hujan mulai dari Bulan Januari hingga minggu pertama Bulan Mei (BMKG 2018). Hal ini sedikit berbeda dengan kondisi di lapangan dimana musim hujan masuk pada bulan Februari 2019 dan hasil informasi dari nelayan lokal menyatakan bahwa pada bulan Desember - Januari kondisi laut sedang mengalami gelombang besar, sehingga pengamatan terhadap pesut sulit dilakukan.

Berdasarkan hasil pengamatan di lapangan, kemunculan pesut sebagian besar terjadi pada cuaca yang mendung, berawan, kondisi air tenang hingga berombak kecil dan air cenderung keruh karena air laut sedang naik/pasang. Kondisi cuaca diduga berpengaruh terhadap kemunculan pesut mahakam, karena banyaknya ikan kecil yang bermunculan pada saat kondisi berawan hingga mendung dibandingkan dengan saat kondisi cuaca cerah. Suhu perairan umumnya sangat berpengaruh terhadap migrasi mamalia laut, baik paus maupun lumbalumba. Suhu perairan mempengaruhi penyebaran dan ketersediaan makanan bagi mamalia laut. Sebagian dari paus atau lumba-lumba hidup pada perairan yang hangat. Migrasi yang dilakukan mamalia ke daerah ekuator dari arktik dan antartika bertujuan untuk mendapatkan makanan dan untuk beradaptasi terhadap suhu hangat (Andersen 1969 dalam Wahyudi 2010). 


\section{c. Pakan}

Menurut informasi nelayan lokal menyatakan bahwa pesut mahakam sering terlihat memakan ikan ikan kecil seperti kembung serta udang. Kreb (2004) menyatakan pesut mahakam memakan ikan, cepalopoda, dan krustacea. Tempat yang disukai pesut mahakam salah satunya adalah wilayah-wilayah yang menyediakan sejumlah besar ikan dan hewan air yang menjadi makanannya. Pesut mahakam juga menyukai lokasi pertemuan (muara) anak sungai (Noor 2016). Pertemuan arus anak-anak sungai dengan induknya, menciptakan pusaran air yang kuat. Kekuatan pusaran akan memerangkap berbagai jenis ikan yang menjadi mangsa pesut mahakam. Perangkap pusaran arus akan membuat ikan menjadi lebih mudah diburu oleh pesut mahakam. Anak-anak sungai juga merupakan jalan keluar bagi ikan-ikan dari rawa ke sungai besar sehingga muaranya menjadi tempat di mana pesut mahakam menunggu mangsanya. Perilaku pesut mahakam terkadang menyemprotkan air ketika berburu yang bertujuan untuk memancing ikan (Noor 2016).

\section{SIMPULAN}

Pendugaan populasi pesut (Orcaealla brevirostris) yang ada di Resort Sungai Perlu Seksi Pengelolaan Wilayah II TNTP pada bulan Februari 2019 berjumlah 55 individu. Berdasarkan hasil pengamatan, pesut banyak terlihat bermunculan pada kondisi cuaca berawan dan mendung, dengan kondisi air menuju pasang, pesut juga banyak ditemukan pada pertemuan arus sungai karena pada kondisi tersebut banyak ditemukannya ikan-ikan kecil sebagai pakannya. karakteristik sirip punggung pesut berbeda beda di antaranya bulat telur, bergerigi, datar dan segitiga sehingga dapat menjadi penanda dalam setiap individu. Keberadaan pesut di TNTP Resort Sungai Perlu menandakan habitat yang potensial bagi pesut berdasarkan temuan tersebut diatas.

\section{DAFTAR PUSTAKA}

Balai Taman Nasional Tanjung Puting. 2017. Tipologi Resort Sugai Perlu Taman Nasional Tanjung Puting. Kuala Pembuang: Balai TNTP

Baumgartner MF, Mate BR. 2005. Summer and fall habitat of North Atlantic right whales (Eubalaena glacialis) inferred from satellite telemetry. Can. J. Fish. Aquat. Sci. 62: 527-543.

Beasley IL. 2007. Conservation of The Irrawaddy Dolphin Orcaella brevirostris (Owen in Gray 1866) in The Mekong River: Biological and Social Considerations Influencing Management. North Queensland: School of Earth and Environtmental Science, James Cook University.

[BMKG] Badan Metorologi Limatologi Dan Geofisika. 2018. Buku Prakiraan Musim Hujan 2018/2019. Jakarta: BMKG.
Daura-Jorge FG, Wedekin LL, Piacentini VQ, SimoesLopes PC. 2005. Seasonal and daily patterns of group size, cohesion and activity of the estuarine dolphin, Sotalia guianensis (PJ van Bénéden) (Cetacea, Delphinidae), in southern Brazil. Rev. Bras. Zool. 22:1014-1021.

Departemen Kehutanan RI. 2008. Permenhut No. P.57/Menhut-II/2008. Arahan Strategis Konservasi Spesies Nasional 2008 - 2018. Jakarta: Departemen Kehutanan

Hammond PS, Mizroch SA, Donovan GP. 1990. Individual recognition of cetaceans: use of photoidentification and other techniques to estimate population parameters. Cambridge: Int. Whaling Commission.

Harzen S. 1998. Habitat use for bottlenose dolphin (Trusiops Truncates) in Sado Estuary, Portugal. Blue Dolphin Research and Consulting. Mamals. 24(3):117-12

[IUCN] International Union for Conservatio of Nature. 2017. Irrawaddy dolphin. www.iucnredlist.org.

Kementerin Lingkungan Hidup dan Kehutanan. 2018. MEN-LHK No. P.20 /MENLHK/ SETJEN/ KUM.1/6/2018. Jakarta: KLHK

Kreb D. 2004. Abundance of freshwater irrawaddy dolphins in the Mahakam River in East Kalimantan, Indonesia, based on mark-recapture analysis of photo-identified individuals. $J$ Cetacean Res Manage. 6(3):269-277

Leatherwood S, Reeves RR. 1994. River dolphins: a review of activities and plans of the Cetacean Specialist Group. Aquat. Mamm. 20:137-154.

Noor IY. 2016. Pesut, Profil Peluang Kepunahan dan Upaya Konservasinya. Balikpapan: Pusat Pengendalian Pembangunan Individu Region Kalimantan. Kementerian Lingkungan Hidup dan Kehutanan.

Noor IY, Basuni S, Kreb D, Kartono AP. 2013. Kelimpahan dan sebaran populasi pesut (Orcaella brevirostris Gray, 1866) di Sungai Mahakam Kalimantan Timur. Jurnal Penelitian Hutan dan Konservasi Alam. 10(3):283 - 296

Parra GJ, Corkeron P. 2001. The feasibility of using photoidentification techniques to study the irrawaddy dolphin, Orcaella brevirostris (Owen in Gray 1866). Aquat. Mamm. 27:45-9.

Purnomo A, Rifanjasi S, Wahdina. 2017. Sebaran pesut (Orcaella brevirostris) di perairan Kabupaten Kubu Raya dan di Perairan Kabupaten Kayong Utara Provinsi Kalimantan Barat. Jurnal Hutan Lestari. 5(1):28 - 33

Wahyudi D. Karakteristik Habitat Mamalia Laut di Perairan Kepulauan Seribu, Jakarta Utara. 2010. Bogor: Departemen Manajemen Sumberdaya Perairan Fakultas Perikanan dan Ilmu Kelautan Institut Pertanian Bogor. 
[WWF] World Wild Fund Kamboja. 2017. Ensuring A Bright Future of Irrawaddy Dolphins in The Mekong River. Cambodia: WWF.
[WWF] World Wild Fund. 2019. Irrawaddy Dolphin. https://wwf.panda.org

\section{Lampiran 1 Tabel Sirip Punggung Pesut (Orcaella brevirostris)}

\begin{tabular}{|c|c|c|c|}
\hline No. & $\begin{array}{c}\text { Kode Sirip } \\
\text { Punggung }\end{array}$ & Foto & Keterangan \\
\hline 1. & PST001 & & $\begin{array}{l}\text { Bentuk sirip membundar dengan ujung sirip } \\
\text { membentuk lekukan ke dalam }\end{array}$ \\
\hline 2. & PST002 & & $\begin{array}{l}\text { Bentuk sirip melonjong dengan sedikit } \\
\text { menukik ke atas, bentuk sirip agak tajam. }\end{array}$ \\
\hline 3. & PST003 & & Bentuk sirip membundar. \\
\hline 4. & PST004 & & $\begin{array}{l}\text { Sirip membentuk dua lekukan dengan ujung } \\
\text { melancip dan tajam dimana salah satu lekukan } \\
\text { mempunyai ujung yang membentuk angka tiga. }\end{array}$ \\
\hline
\end{tabular}




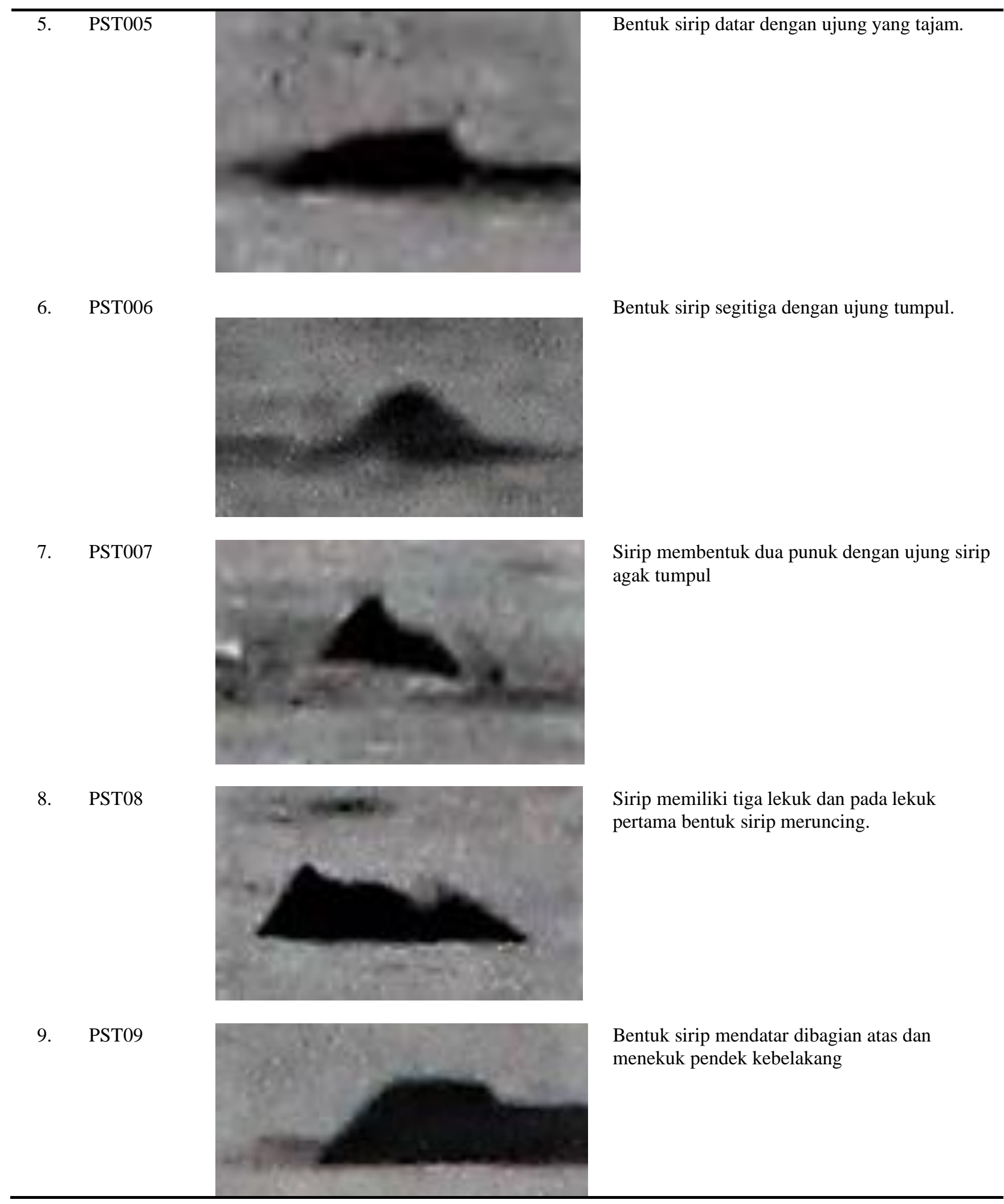




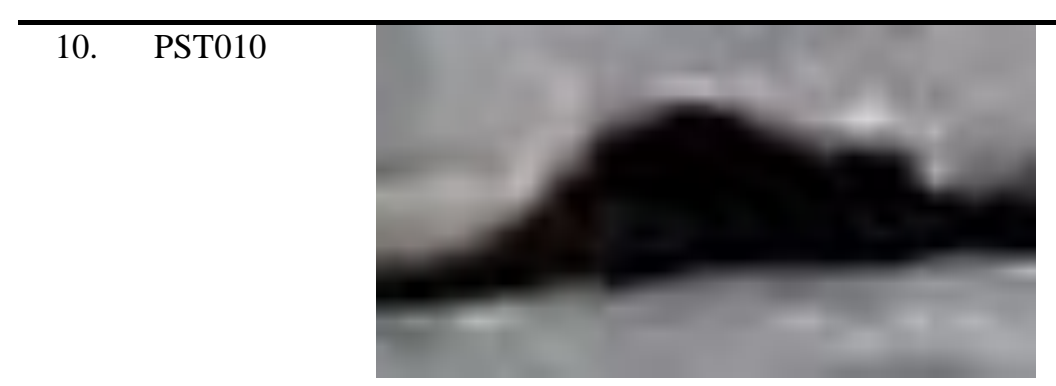

11. PST011

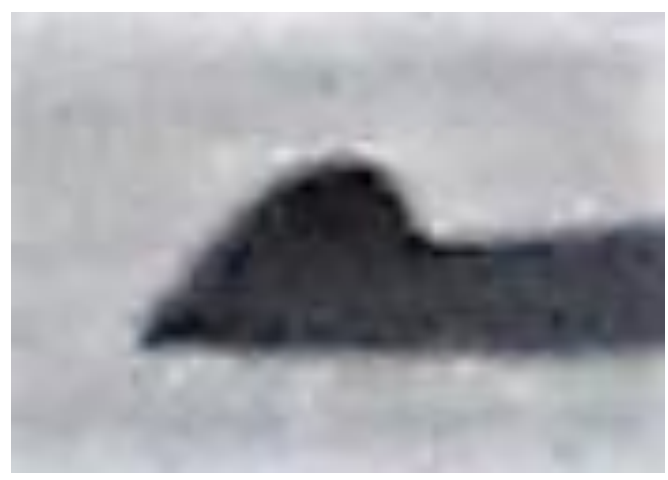

12. PST012

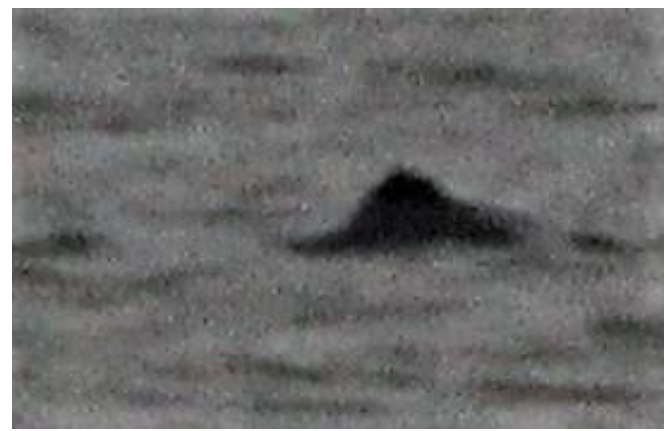

13. PST013

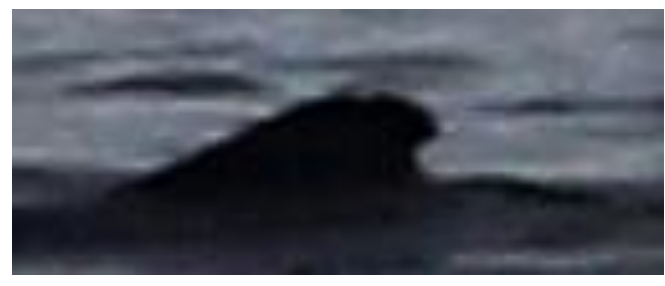

14. PST014

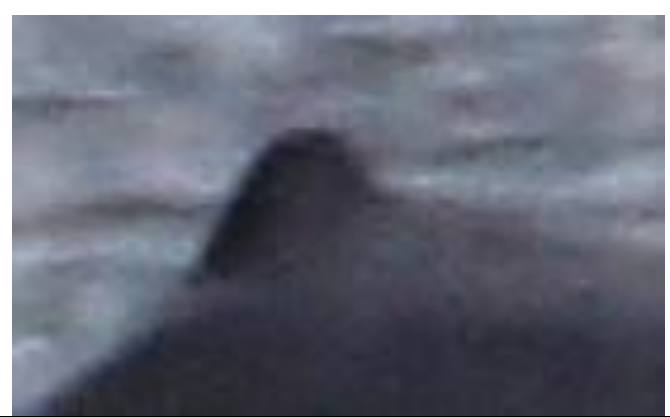

Bentuk sirip tak beraturan dengan puncak sirip seperti atap.

Bentuk sirip membundar dan agak melengkung kebelakang.

Bentuk sirip mirip segitiga dengan ujung tumpul dan melebar.

Bentuk sirip menukik kebelakang dengan adanya cekung cukup dalam pada sirip.

Bentuk sirip kecil dan bundar pada ujung sirip. 


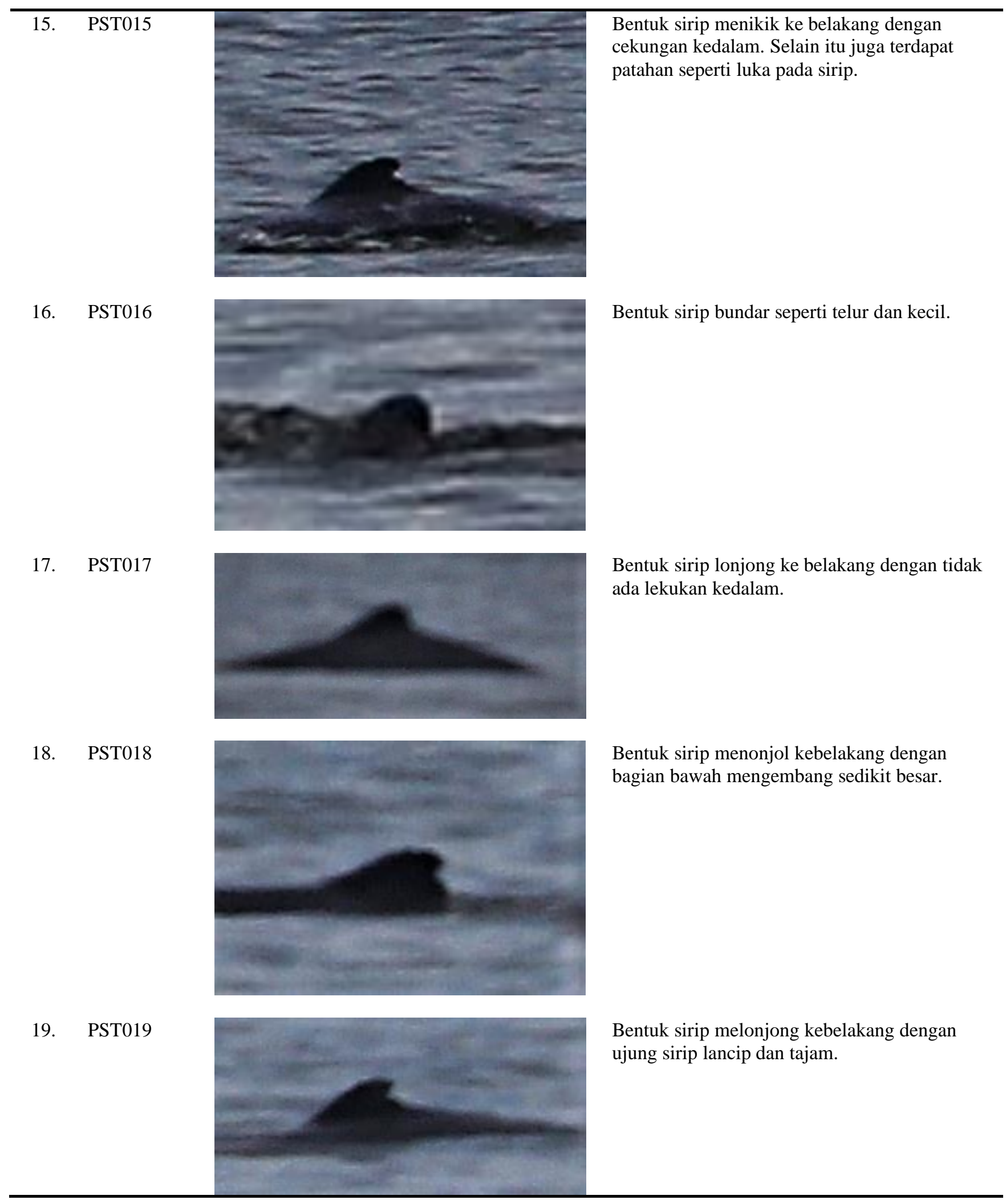




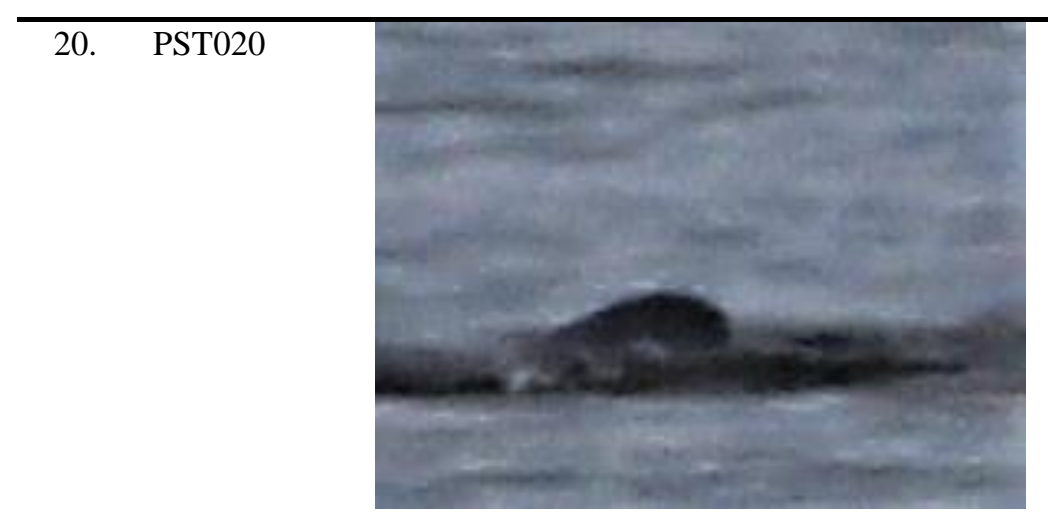

Bentuk sirip pendek dan rendah. Sirip membundar namun tidak tebal.

21. PST021

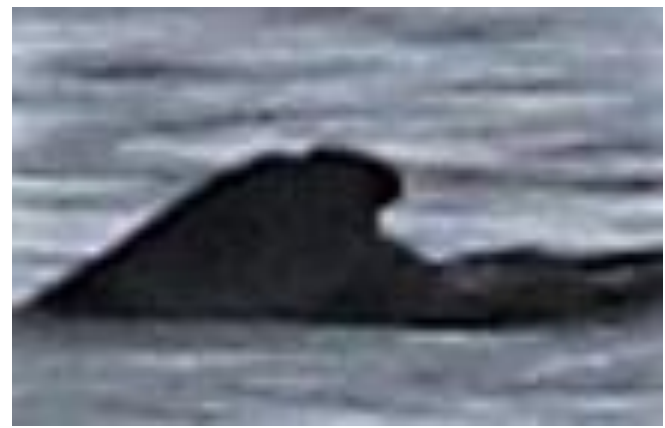

Bentuk sirip lonjong dan menekuk di belakang serta terdapat lekukan kecil pada puncak sirip.

22. PST022

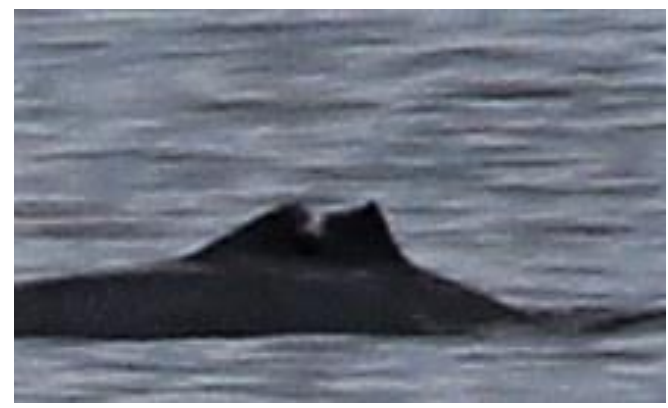

Bentuk sirip tajam dengan patahan yang terlihat nyata membentuk lekukan di tengah.

23. PST023

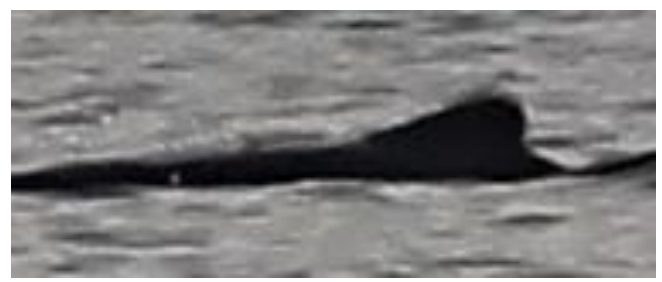

Bentuk sirip membundar di ujung.

24. PST024

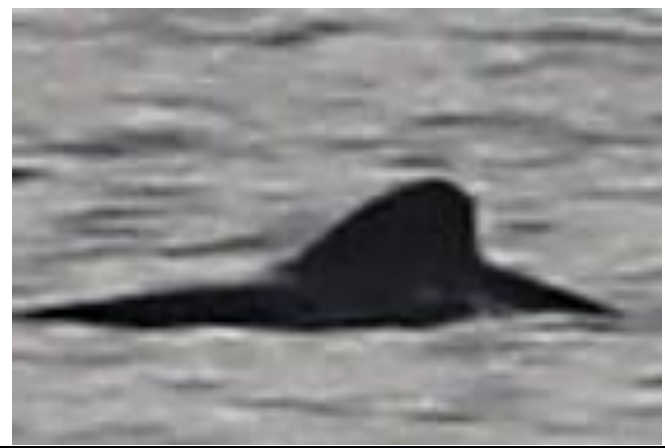

Sirip menyerupai segitiga sama sisi dengan ujung membundar. 


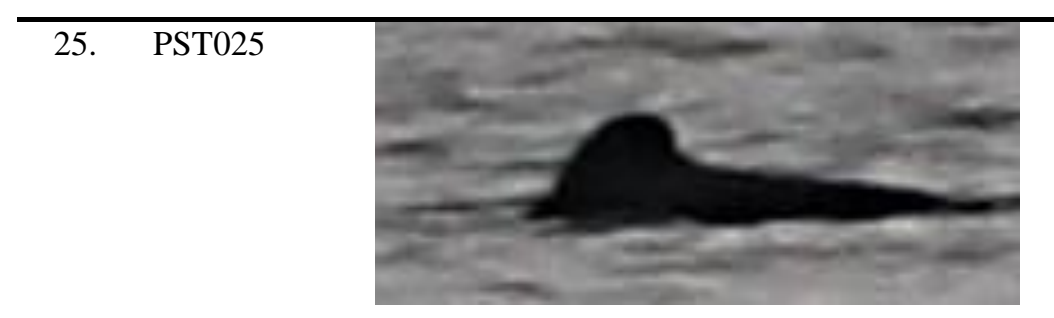

26. PST026

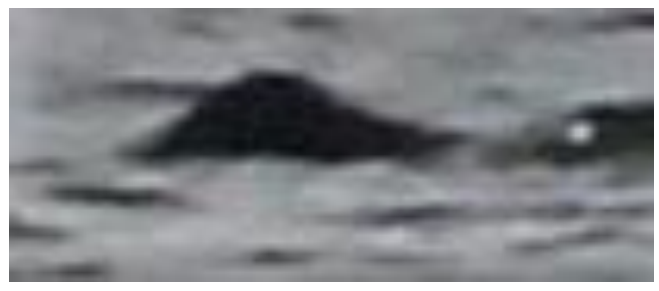

27. PST027

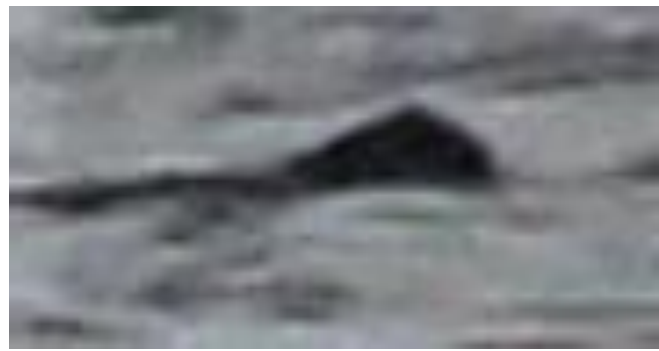

28. PST028

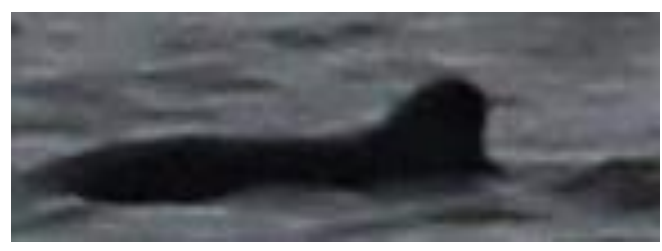

29. PST029

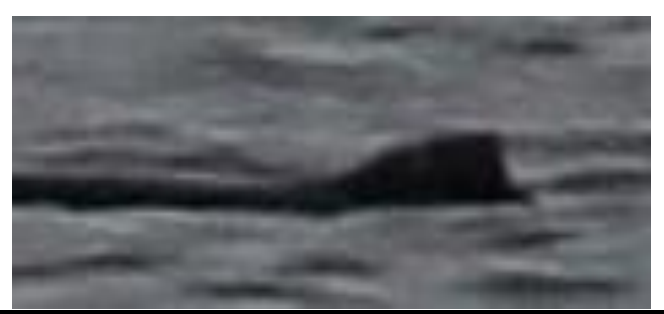

Bentuk sirip setengah lingkaran dengan

lekukan sedikit ke dalam.

Sirip membentuk segitiga tumpul dan pendek.

Bentuk sirip menyerupai segitiga dengan bagian belakang mematah ke bawah.

Bentuk sirip bulat telur.

Bentuk sirip segitiga sama sisi dengan ujung langsung membentuk patahan kebawah. 